\title{
CITRA MEREK, KUALITAS PRODUK, HARGA DAN PENGARUHNYA PADA MINAT BELI ULANG PRODUK KECANTIKAN WARDAH
}

\author{
Silvia Nurfitriana ${ }^{1)}$ dan Francy Iriani ${ }^{2)}$ \\ ${ }^{1,2}$ Manajemen, Fakultas Ekonomi dn Bisnis, Universitas Trilogi \\ ${ }^{1,2}$ J1 Kampus STEKPI No 1 Kalibata, Jakarta, 12760 \\ E-mail : francy@trilogi.ac.id ${ }^{1)}$, silvianurvitriana79@ gmail.com ${ }^{2)}$
}

\begin{abstract}
ABSTRAK
Berdasarkan award yang diberikan untuk katagori kosmetik tahun 2018, Wardah merupakan salah satu merek yang masuk dalam katagori produk paling diminati konsumen Positioning produk sebagai produk yang halal juga menarik minat peneliti untuk melihat apakah terdapat pengaruh dari citra merek, kualitas produk dan harganya terhadap minat beli ulang produk kecantikan produksi PT Paragon Technology and Innovation ini. Penelitian ini merupakan explanatory reserch yang berusaha menjelaskan hubungan kausal antara variabel bebas berupa Citra Merek, Kualitas Produk dan Harga dengan variabel terikat yaitu Minat Beli Ulang. Penelitian dilakukan di Jakarta. Sampel penelitian diambil menggunakan teknik non probability sampling dengan sampling purposive, dan sampel penelitian diambil sebanyak 150 responden, sesuai perhitungan rumus SEM, jumlah indikator dikalikan sepulusilvianurfitriana79@gmail.cinh. Data primer diperoleh dengan cara menyebarkan kuesioner dengan menggunakn skala likert. Data kemudian diolah dengan menggunakan pendekatan Partial Least Square (PLS) dengan menggunakan software SmartPLS versi 20.m3. Hasil penelitian ini Variabel Citra Merek yang terdiri dari dimensi Identitas Merek dan Citra poduk berpengaruh positif terhadap Minat Beli Ulang. Variabel Kualitas Produk berpengaruh positif terhadap Minat Beli. Variabel Harga berpengaruh positif terhadap Minat Beli Ulang Produk. variabel yang paling berpengaruh terhadap Minat Beli Ulang adalah Kualitas Produk.
\end{abstract}

Kata Kunci: Citra merek, Kualitas Produk, Harga, Minat beli ulang, Kosmetik.

\section{PENDAHULUAN \\ Hampir seluruh produk kosmetik didunia ini} mengandung campuran alkohol dimana senyawa tersebut dinyatakan dianggap haram oleh agama Islam jika digunakan pada tubuh. Untuk itu PT Paragon Technology and Innovation melihat peluang pemasaran produk kosmetik yang halal bagi wanita muslimah di Indonesia. Positioning ini menarik karena Islam merupakan agama yang besar di Indonesia dan persaingan antar merek di industri kosmetik cukup ketat. Jika dilihat dari Top Brand Research (Frontier Mark Plus, 2018) pada phase 1, Wardah menempati urutan merek top pada katagori kosmetik, antara lain Lipstik, lipgloss, mascara dan blush on. Wardah di atas merek Revlon, Pixy, Viva, Sariayu, Oriflame, La Tulipem dan lainnya. Hanya pada kategori maskara Wardah di bawah merek Maybeline.

Produk Wardah adalah produk yang pure and safe, yang mengandung bahan baku yang aman dan halal. Sebelum sebuah produk Wardah dijual di pasaran maka dilakukan suatu percobaan yang dinamakan blind test yang bertujuan untuk memastikan bahwa produk yang akan dijual aman. Wardah juga mengklaim bahwa perusahaannya adalah beauty expert. Wardah diproduksi sesuai dengan karakter kulit dari wanita Indonesia. Inspiring beauty sebagai tagline Wardah adalah suatu pernyataan yang berarti bahwa produk yang dihasilkan oleh Wardah dapat memberikan kepercayaan diri bahwa dirinya cantik dan kecantikan ini berasal dari kosmetik Wardah yang digunakannya.
Banyak cara yang bisa dicapai oleh perusahaan untuk meningkatkan keputusan pembelian, misalnya dengan memperhatikan faktor harga. Pada umumnya, pelanggan cenderung akan memilih perusahaan yang menawarkan produknya dengan harga yang relative murah. Harga merupakan salah satu bahan pertimbangan yang penting bagi konsumen untuk membeli produk pada suatu perusahaan. PT Paragon Technology and Innovation (PTI) ini juga menetapkan harga yang relative murah dan dapat dijangkau oleh semua lapisan masyarakat. Hal ini merupakan strategi yang sangat baik untuk bisa bertahan dalam persaingan dengan perusahaan sejenis.

Andikarini dalam penelitian di Yogyakarta dengan judul yang mirip mendapatkan hasil bahwa persepsi kualitas produk, citra merek dan harga berpengaruh positif terhdap keputusan membeli produk Wardah. Sulistryari yang meneliti variable yang sama, untuk produk yang berbeda,tetapi menggunakan metode pengolahan data regresi berganda, menampakkan hasil pengaruh positif dari citra merek, kualits produk dan harga terhadap minat beli di Semarang. Henry Aspan, meneliti pengaruh Label Halal, Awareness Halal, Produk, Harga dan Citra Merek untuk keputusan pembelian kosmetik. Untuk itu peneliti ingin melihat apakah variabel kualitas produk, Harga dan Citra Merek, dengan dua dimensi yang menyertai yaitu identitas merek dan citra produk yang akan dilihat terlebih dahulu pengaruhnya terhadap citra merek, di wilayah Jakarta, akan memberikan hasil penelitian yang sama, atau ada perbedaan untuk responden. Selain itu, dalam 
pengolahan data, peneliti menggunakan metode SEM (structural equation modelling) menggunakan partial least squares path modelling (PLS_SEM), metode yang lebih akurat dalam memprediksi pengaruh variabel independen terhadap variabel dependen.

\section{RUANG LINGKUP}

Dalam penelitian ini permasalahan mencakup:

1. Cakupan permasalahan dalam penelitian ini antara lain :Bagaimana pengaruh Citra Merek terhadap Minat Beli Ulang produk kecantikan Wardah? Bagaimana pengaruh Kualitas Produk terhadap Minat Beli Ulang produk kecantikan Wardah? Bagaimana pengaruh Harga terhadap Minat Beli Ulang produk kecantikan Wardah? Dan Bagaimana pengaruh Citra Merek, Kualitas Produk dan Harga terhadap Minat Beli Ulang produk kecantikan Wardah?

2. Responden dibatasi untuk wilayah Jakarta, dan dibatasi pada jenis kelamin wanita dengan usia 17 tahun keatas.

3. Hasil penelitian ini bermanfaat untuk penelitian lebih lanjut dengan tambahan variabel promosi, product endorsement, dan responden dari kota kota besar di Indonesia seperti Medan, Makassar, Yogyakarta dan Surabaya.

\section{BAHAN DAN METODE}

Pengertian pemasaran menurut Armstrong, Kotler, Thrifts dan Buchwitz (2017) adalah "Proses dimana perusahaan menciptakan nilai bagi pelanggan dan membangun hubungan pelanggan yang kuat dan sebagai balasannya, mendapatkan value dari pelanggan”. Bauran pemasaran didefinisikan oleh Solomon, Marshall dan dan Stuart (2018) sebagai "kombinasi dari produk itu sendiri, harga produk, kegiatan promosi yang mengenalkannya, dan tempat dimana produk itu tersedia, yang bersamasama menciptakan respons yang diinginkan di antara sekumpulan konsumen yang telah ditentukan...bauran pemasaran yaitu produk, harga. promosi, dan tempat". Untuk menciptakan nilai yang berguna bagi pelanggan, perusahaan perlu antara lain mengembangkan citra mereknya sesuai dengan perspsi yang diinginkan pelanggan, menetapkan harga yang tepat, promosi yang sesuai dengan daur hidup produk dan lain lain. Dalam penelitian ini, beberapa variabel yang diteliti dan diduga berkaitan dengan minat beli kembali konsumen antara lain citra merek, kualitas produk dan harga.

\subsection{Merek dan Citra Merek}

Asosiasi Marketing Amerika memberikan definisi merek sebagai berikut : "Suatu merek adalah nama, istilah, simbol, atau desain, atau kombinasi dari keduanya, yang dimaksudkan untuk mengidentifikasi barang dan jasa dari satu penjual atau kelompok penjual dan untuk membedakannya dari pesaing" (Keller;2013). Tilde Heding, Charlotte F. Knudtzen dan Mogens Bjerre (2009) menyatakan bahwa “...merek dikaitkan dengan identifikasi suatu produk dan diferensiasi dari para pesaingnya". Jadi pesaing merupakan salah satu alasan mengapa merek perlu menjadi alat diferensiasi suatu produk termasuk kosmetik. Tjiptono \& Diana (2016) menyatakan, citra merek berkenaan dengan persepsi konsumen terhadap sebuah merek. Tujuan upaya strategik mengelola citra merek adalah memastikan bahwa konsumen memiliki asosiasi kuat dan positif dalam benaknya mengenai merek perusahaan. Elemen citra merek terdiri atas: (1) persepsi, karena konsumen mempersepsikan merek; (2) kognisi, karena merek dievaluasi seacara kognitif; (3) sikap, karena konsumen membentuk sikapnya terhadap suatu merek setelah mempersepsian dan mengevaluasi merek bersangkutan.

Menurut Tjiptono (2015) "Citra merek adalah deskripsi asosiasi dan keyakinan konsumen terhadap merek tertentu. Citra merek (Brand Image) adalah pengamatan dan kepercayaan yang digenggam konsumen, seperti yang dicerminkan di asosiasi atau di ingatan konsumen".

Untuk banyak pembelian, citra merek yang terbentuk melalui variabel nonproduk, yaitu, harga, promosi, dan saluran distribusi menjadi penentu paling menentukan pembelian (Peter \& Olson, 2014).

Keller (2013): salah satu aspek penting dari merek adalah citranya, sebagaimana tercermin dari asosiasi tersebut memungkinkan para pemasar untuk membuat perbedaan antara tingkat persaingan terhadap citra spesifik dari konsumen nya dan manfaat dengan tingkat dari level yang lebih tinggi. Menurut Keller (2013) 'brand image is cunsomer' perceptions about a brand, as reflected by the brand associations held in consumer memory." Keller mengatakan citra merek merupakan persepsi konsumen mengenai merek yang tercermin oleh asosiasi merek yang tercipta di memori konsumen. Menciptakan citra merek yang positif yaitu dengan mengambil program pemasaran yang menghubungkan asosiasi yang kuat, menguntungkan, dan unik untuk merek dalam ingatan.

Asosiasi merek dapat berupa atribut atau manfaat merek. Atribut merek adalah berbagai fitur deskripstif yang menjadi ciri produk atau layanan. Manfaat merek adalah nilai personal dan makna yang konsumen lampirkan pada atribut produk atau jasa. Konsumen membentuk keyakinan tentang atribut merek dan manfaat dalam cara yang berbeda. Ini berarti bahwa konsumen dapat membentuk asosiasi merek dalam berbagai cara lain selain kegiatan pemasaran, seperti : dari pengalaman langsung, penelusuran online, melalui informasi dari sumber-sumber komersial atau non partisan lain seperti laporan konsumen atau media lainnya, dari mulut ke mulut, dengan asumsi atau kesimpulan yang dibuat konsumen atas merek itu sendiri yaitu nama, logo atau identifikasi dengan sebuah perusahaan, Negara, saluran distribusi, atau orang, tempat, atau peristiwa. Asosiasi yang unik membantu konsumen memilih merek. 
Berdasarkan uraian di atas dapat disimpulkan bahwa citra merek merupakan serangkaian kepercayaan konsumen tentang merek tertentu sehingga asosiasi merek tersebut melekat di benak konsumen. Indikator yang mempengaruhi citra merk (Kotler 2012:262), yaitu:1. Persepsi konsumen terhadap pengenalan produk, 2.Persepsi konsumen terhadap kualitas produk, 3.Persepsi konsumen terhadap ukuran, 4.Persepsi konsumen terhadap daya tahan, 5. Persepsi konsumen terhadap warna produk, 6. Persepsi konsumen terhadap harga, 7. Persepsi konsumen terhadap lokasi.

\subsection{Kualitas produk}

Kotler dan Amstrong (2014) mengatakan "produk adalah semua hal yang dapat ditawarkan kepada pasar untuk menarik perhatian, akuisisi, penggunaan, atau konsumsi yang dapat memuaskan satu keinginan atau kebutuhan. Kualitas produk menurut Armstrong, Kotler, thrifts dan buchwitz (2017) sebagai "Karakteristik suatu produk atau suatu layanan yang ditanggung dalam kemampuannya untuk memuaskan kebutuhan pelanggan baik yg dinyatakan maupun yg tersirat”. Klasifikasi Produk Menururt Kotler dan Keller (2012) ada tiga, yaitu berdasarkan daya tahan dan keberwujudan produk, berdasarkan penggunaan klasifikasi barang konsumen dan klasifikasi barang industri.

\subsection{Harga Produk.}

Harga yang sesuai dengan keinginan dan persepsi dari konsumen dapat memberikan pengaruh yang kuat terhadap minat beli ulang konsumen. Ini dibuktikan pada penelitian Aspan, sipayung dan Muharrami (2017), Solomon (2018) mendefinisikan harga sebagai "Penetapan nilai. atau jumlah yang harus ditukarkan oleh konsumen untuk menerima penawaran". Harga adalah apa yang harus diserahkan pelanggan untuk mendapatkan manfaat produk yg ditawarkan bersama bauran pemasaran perusahaan" (Kotler,2018). Menurut Kotler, harga memiliki beberapa indikator, antara lain : Keterjangkauan harga, Daya saing harga, Kesesuaian harga dengan kualitas produk.

\subsection{Minat Beli Ulang.}

Penilaian konsumen terhadap produk tergantung pada pengetahuannya akan informasi tentang fungsi sebenarnya dari produk tersebut, konsumen yang akan berminat untuk melakukan pembelian ulang suatu produk dipengaruhi oleh informasi yang diterima. (Schiffman dan Wisenbilt:2015). Minat beli ulang dapat diidentifikasi melalui indikator sebagai berikut:1. Minat transaksional. Minat transaksional yaitu kecenderungan seseorang untuk membeli produk. 2. Minat referensial. Minat referensial yaitu kecenderungan seseorang untuk mereferensikan kepada orang lain.3.Minat preferensial. Minat preferensial yaitu minat menggambarkan perilaku seseorang yang memiliki preferensi utama pada produk, preferensi ini hanya dapat diganti bila terjadi sesuatu dengan produk preferensinya.(Ali,Hasan:2013).

\subsection{Tahapan Penelitian}

Penelitian ini menggunakan data primer (Sugiono, 2016) berupa kuesioner (Sujarweni, 2015) dengan menggunakan skala likert sebagai berikut :

Tabel 1. Skala Likert

\begin{tabular}{|l|c|}
\hline Pernyataan & Skor \\
\hline Sangat Setuju & 4 \\
\hline Setuju & 3 \\
\hline Tidak Setuju & 2 \\
\hline Sangat Tidak Setuju & 1 \\
\hline
\end{tabular}

Variabel dalam penelitian ini: citra merek (X1), kualitas produk (X2) dan harga (X3) terhadap minat beli konsumen (Y). Populasi pengguna kosmetik merek Wardah tidak diketahui. Sampel penelitian diambil secara non probability sampling dengan jenis sampling purposive, yaitu responden dipilih dari pengguna kosmetik merek ini dengan usia 17 tahun keatas (Sugiyono,2016). Dalam penelitian yang menggunakan SEM ini, ukuran sampel yang digunakan adalah indikator dikalikan 10 dengan kesimpulan akhir yaitu jumlah sampel adalah 150 sampel. (Ferdinand dalam Sanusi:2011). Data diolah dengan metode SEM (structural equation modelling) menggunakan partial least squares path modelling (PLS_SEM) dengan software smart PLS 3.0. Analisis PLS_SEM biasanya terdiri dari dua sub model yaitu model pengukuran (meansurement model) atau sering disebut outer model dan model structural (structural model) atau sering disebut inner model. Model ini juga digunakan untuk mengukur valmodel structural menunjukkan estimasi antar variabel laten atau konstruk, model ini juga digunakan untuk mengetahui apakah variabel Citra Merek (X1), Kualitas Produk (X2) dan Harga (X3) berpengaruh terhadap Minat Beli Ulang (Y).

Berdasarkan landasan teori dan penelitian yang di uraikan diatas, maka kerangka adalam penelitian ini adalah sebagai berikut:

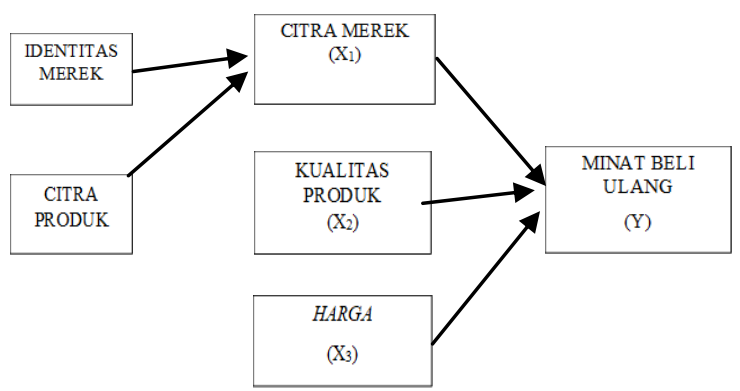

Gambar 1. Kerangka Penelitian.

Pada gambar diatas terlihat bahwa citra merek memiliki dimensi identitas merek dan citra produk. Minat beli ulang produk sebagai variabel dependen (Y) 
dipengaruhi oleh tiga variabel independen, yaitu citra merek (x1), Kualitas produk (X2) dan Harga (X3).

\section{PEMBAHASAN}

Berikut disajikan hasil survey dan gambaran informasi dari responden

\subsection{Gambaran Umum Responden.}

Adapun jumlah responden yang diperoleh dalam penelitian ini berdasarkan usianya, 17-25 tahun sebesar 84,7 \%. 26-36 tahun sebesar 9,3\%, 5,3\% dari usia 37-47 thn dan diatas 47 thn sebanyak $1 \%$. Berdasarkan pekerjaannya, responden dikelompokkan sebagai berikut: Pekerjaan terbanyak adalah mahasiswa yaitu sebanyak 74 orang atau $49 \%$. Ibu rumah tangga 6\%, Karyawati $27,4 \%$, wiraswasta $6,7 \%$, PNS $1,3 \%$ dan lainnya sebanyak 9,3\%, sehingga jumlahnya 150 responden. Berdasarkan tingkat pendidikannya, SD dan SMP masing masing $1 \%$, SMA $52 \%$ atau sebanyak 79 orang, D3 sebanyak $5 \%$ atau orang 7, S1 $39 \%$ atau 58 orang dan S 2 sebanyak $2 \%$ atau 3 orang. ( Sumber: Data primer, diolah 2018).

Adapun jawaban responden terhadap pertanyaan yang diajukan dalam bentuk kuesioner atau data primer adalah sebagai berikut :

\subsection{Citra Merek Produk Kecantikan Wardah di Jakarta}

1. Identitas Merek:

Adapun jawaban responden terhadap pernyataan dalam kuesioner mengenai Identitas merek adalah sebagai berikut:

1) Pada pernyataan nomer 1 "Kosmetik wardah memiliki logo yang khas dengan warna silver disetiap kemasan" sebagian besar responden menjawab setuju dan sangat setuju sebanyak 143 orang (95\%). Logo Produk Kosmetik Wardah memiliki ciri khas warna silver disetiap kemasan.

2) Pada pernyataan nomer 2 "Warna kosmetik wardah soft dan elegan“ sebagian besar responden menjawab setuju dan sangat setuju dengan jumlah 145 orang (97\%). Sehingga dapat disimpulkan warna kosmetik wardah soft dan elegan.

3) Pada pernyataan nomer 3 "Kombinasi warna kosmetik wardah menarik " sebagian besar responden menjawab setuju dan sangat setuju dengan jumlah 141 orang (94\%). Sehingga dapat disimpulkan bahwa warna kosmetik wardah menarik.

4) Pada pernyataan nomer 4 "wardah memiliki slogan yang mudah diingat " sebagian besar responden menjawab setuju dan sangat setuju dengan jumlah 134 orang (90\%). Sehingga dapat disimpulkan bahwa wardah memiliki slogan yang mudah di ingat.

5) Pada pernyataan nomer "Merek kosmetik wardah mempunyai reputasi yang baik" sebagian besar responden menjawab setuju dan sangat setuju dengan jumlah 150 orang (100\%). Sehingga dapat disimpulkan bahwa Merek kosmetik wardah mempunyai reputasi yang baik.

\section{Citra Produk}

Jawaban Responden pada pernyataan dalam kuesioner adalah sebagai berikut :

1) Pada pernyataan nomer 6 "Produk yang halal produk yang penting buat saya " sebagian besar responden menjawab setuju dan sangat setuju dengan jumlah 148 orang (99\%). Sehingga dapat disimpulkan bahwa produk wardah memberikan jaminan akan kehalalan produknya.

2) Pada pernyataan nomer 7 "Produk kosmetik wardah mudah untuk diingat" sebagian besar responden menjawab setuju dan sangat setuju dengan jumlah 146 orang (97\%). Sehingga dapat disimpulkan bahwa produk kosmetik wardah memberikan kemudahan untuk di ingat oleh konsumenya.

3) Pada pernyataan nomer 8 "Bentuk kemasan kosmetik wardah mempermudah dalam menggunakan kosmetik wardah " sebagian besar responden menjawab setuju dan sangat setuju dengan jumlah 143 orang (95\%). Sehingga dapat disimpulkan bahwa kosmetik wardah memberikan kemudahan dalam menggunkan produknya.

4) Pada pernyataan nomer 9 "Label halal pada produk kosmetik wardah menjamin kehalalan produk " sebagian besar responden menjawab setuju dan sangat setuju dengan jumlah 145 orang (95\%).sehingga dapat di simpulkan bahwa Kosmetik wardah menjamin kehalalan produk yang di sertai dengan logo halalnya.

5) Pada pernyataan nomer 10 "Informasi label halal LPPOM MUI pada kemasan memperkuat bahwa kosmetik wardah tidak berbahaya" sebagian besar responden menjawab setuju dan sangat setuju dengan jumlah 145 orang (97\%).sehingga dapat di simpulkan bahwa Kosmetik wardah mempunyai informasi label halal dari LPPOM MUI yang membuat konsumen percaya bahwa produk wardah tidak berbahaya.

\section{Kualitas Produk}

Jawaban responden pada kuesioner mengenai kualitas produk adalah sebagai berikut:

1) Pada pernyataan nomer 11 "Saya percaya bahwa produk halal sangat berkualitas" sebagian besar responden menjawab setuju dan sangat setuju dengan jumlah 142orang (95\%). Sehingga dapat disimpulkan bahwa produk wardah memberikan jaminan akan produk halal yang berkualitas.

2) Pada pernyataan nomer 12 "Produk kosmetik wardah mempunyai beberapa macam produk sesuai jenis kulit "sebagian besar responden menjawab setuju dan sangat setuju dengan jumlah 139 orang (92\%). Sehingga dapat disimpulkan bahwa produk 
kosmetik wardah memberikan beberapa produk yang sesuai dengan jenis kulit.

3) Pada pernyataan nomer 13 "Produk kosmetik wardah memiliki masa pakai yang lama ketika digunakan "sebagian besar responden menjawab setuju dan sangat setuju dengan jumlah 138 orang (92\%). Sehingga dapat disimpulkan bahwa kosmetik wardah memiliki masa pakai yang lama ketika di gunakan.

4) Pada pernyataan nomer 14 "Produk kosmetik wardah bila dipakai tidak luntur " sebagian besar responden menjawab setuju dan sangat setuju dengan jumlah 105 orang (70\%).sehingga dapat di simpulkan bahwa Kosmetik wardahtidak akan luntur bila dipakai.

5) Pada pernyataan nomer 15 "Kosmetik wardah mempunyai beberapa macam produk berbagai warna" sebagian besar responden menjawab setuju dan sangat setuju dengan jumlah 145 orang (97\%).sehingga dapat di simpulkan bahwa Kosmetik wardah memberikan berbagai macam varian warna.

\section{Harga Produk}

Jawaban Responden tehadap pernyataan pada variabel harga produk adalah sebagai berikut :

1) Pada pernyataan nomer 16 "Harga dengan kualitas produk kosmetik wardah sesuai dengan yang ditawarkan" sebagian besar responden menjawab setuju dan sangat setuju dengan jumlah 145 orang (96\%). Sehingga dapat disimpulkan bahwa produk wardah memberikan harga dan kualitas produk yang sesuai dengan apa yang di tawarkan.

2) Pada pernyataan nomer 17 "Produk kosmetik wardah mampu bersaing dan sesuai dengan kemampuan atau daya beli konsumen“ sebagian besar responden menjawab setuju dan sangat setuju dengan jumlah 150 orang (100\%). Sehingga dapat disimpulkan bahwa produk kosmetik wardah mampu bersaing dan sesuai dengan kemampuan atau daya beli konsumen.

3) Pada pernyataan nomer 18 "Biasanya harga produk halal lebih mahal tetapi harga kosmetik wardah tidak mahal" sebagian besar responden menjawab setuju dan sangat setuju dengan jumlah 137 orang (91\%). Sehingga dapat disimpulkan bahwa kosmetik wardah memberikan harga yang murah dari pada produk lainya.

4) Pada pernyataan nomer 19 "Harga produk kosmetik wardah terjangkau namun memiliki kualitas yang baik" sebagian besar responden menjawab setuju dan sangat setuju dengan jumlah 149 orang (\%).sehingga dapat di simpulkan bahwa Kosmetik wardah memberikan harga yang murah namun memiliki kualitas yang baik.

5) Pada pernyataan nomer 20 "Produk kosmetik wardah mampu mengalahkan produk lain yang memiliki harga lebih tinggi diatas produk kosmetik warda " sebagian besar responden menjawab setuju dan sangat setuju dengan jumlah 129 orang (86\%).sehingga dapat di simpulkan bahwa Kosmetik wardah mampu mengalahkan pesaingnya yang harganya lebih tinggi.

\section{Minat Beli Ulang}

Adapun jawaban responden terhadap pernyataan variabel Y minat beli ulang sebagai berikut:

1) Pada pernyataan nomer 21 "Saya akan menyarankan orang lain untuk membeli produk kosmetik wardah" sebagian besar responden menjawab setuju dan sangat setuju dengan jumlah 138 orang (92\%). Sehingga dapat disimpulkan bahwa respondon akan menyarankan orang lain untuk membeli produk kosmetik wardah.

2) Pada pernyataan nomer 22 "Ketertarikan saya untuk menggunakan produk kosmetik wardah karena sudah berlabel halal " sebagian besar responden menjawab setuju dan sangat setuju dengan jumlah 140 orang (75\%). Sehingga dapat disimpulkan bahwa responden menggunkan produk wardah karena adanya label halal.

3) Pada pernyataan nomer 23 "Saya selalu mencari informasi mengenai produk terbaru dari kosmetik wardah " sebagian besar responden menjawab setuju dan sangat setuju dengan jumlah 112 orang (73\%). Sehingga dapat disimpulkan bahwa resonden sealu mencari informasi mengenai produk terbaru dari kosmetik wardah.

4) Pada pernyataan nomer 24 "Jika saya ingin membeli kosmetik saya akan langsung memilih produk kosmetik wardah" sebagian besar responden menjawab setuju dan sangat setuju dengan jumlah 109 orang (\%).sehingga dapat di simpulkan bahwa responden akan langsunng memilih produk kosmetik wardah.

5) Pada pernyataan nomer 25 "Saya ingin selalu menggunakan produk kosmetik wardah “ sebagian besar responden menjawab setuju dan sangat setuju dengan jumlah 115 orang (76\%).sehingga dapat di simpulkan bahwa responden akan selalu menggunakan produk kosmetik wardah.

\subsection{Analisis Data Dengan Partial Least Square}

Data yang akan di analisis adalah variabel Citra Merek (X1), Kualitas Produk (X2), Harga (X3) berpengaruh terhadap Minat Beli Ulang (Y). Berikut ini adalah hasil dari analisis menggunakan SmartPLS 3.0 :

Berikut adalah hasil model algoritma setelah data diolah: 


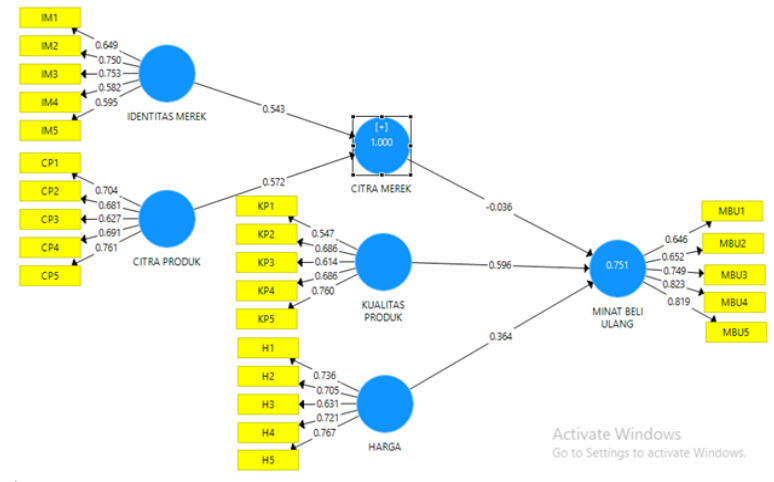

Gambar 2. Model Algoritma.

Hasil ini digunakan untuk melihat uji validitas dan reliabilitas. Indikator dapat dikatakan Convergent Validity karena nilainya berada diatas 0,7. Namun demikian pada riset pengembangan skala, alogaritma 0,50-0,60 masih dapat diterima. Berdasarkan nilai alogaritma di atas, nilai alogaritma telah memenuhi convergent validity karena semua indikator di atas 0,5.

Berikutnya data kemudian diolah dengan model Booth Strapping, dan hasilnya dapat dilihat pada gambar berikut:

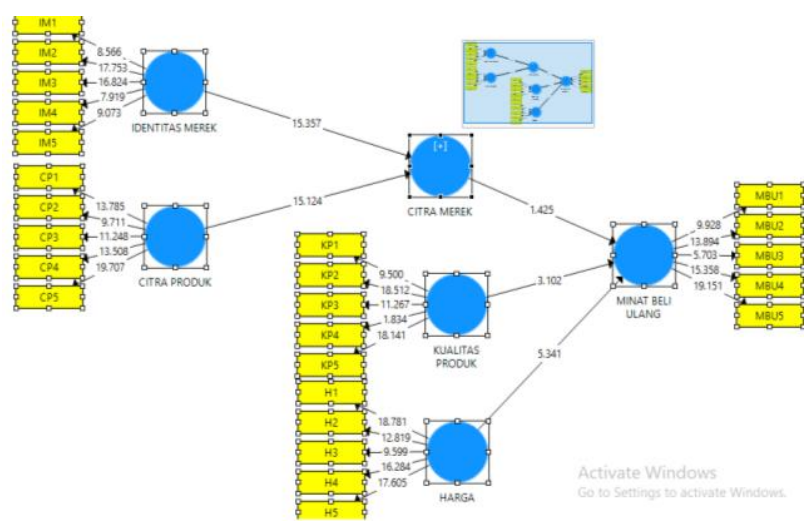

Gambar 3. Model Boothstrapping

Berikutnya dilakukan Evaluasi Model Pengukuran atau Outer Model untuk menguji Validitas \& Reliabilitas model. Uji validitas indikator formatif dievaluasi melalui Convergent Validity dan Discriminant Validity. Sedangkan uji reliablilitas indikator formatif dievaluasi dengan Composite Reliability dan Cronbach's Alpha. Namun demikian penggunaan Cronbach's Alpha untuk menguji reliabilitas konstruk akan memberikan nilai yang lebih rendah (under estimate) sehingga lebih disarankan untuk menggunakan composite reliability dalam menguji reliabilitas suatu konstruk.Berikut adalah hasil dari outer model:

\section{Convergent Validity:}

Untuk uji convergent validity indikator dengan SmartPLS 3.0 dapat dilihat dari nilai outer loading dan nilai Average Variance Extracted (AVE). Uji convergent validity indikator dengan program smartPLS 3.0 yang pertama dapat dilihat dari nilai outer loading pada PLS alogaritma untuk tiap indikator konstruk. Uji lain untuk melihat Convergent Validity adalah melihat nilai AVE pada PLS algoritma. Hasil AVE, secara keseluruhan diatas $\mathrm{O}, 5$ yang berarti bahwa nilai AVE untuk konstruk Citra Merek, Citra Produk, Harga (X1), Identitas Merek(X2), Kualitas Produk(X3) dan Minat Beli Ulang (Y) memiliki nilai AVE lebih besar dari 0,50. Hal ini berarti model AVE baik. Ini dapat dilihat pada tabel 2.:

Tabel 2. Average Variance Extracted (AVE)

\begin{tabular}{|l|l|}
\hline CITRA MEREK & 0,671 \\
\hline CITRA PRODUK & 0,588 \\
\hline HARGA & 0,509 \\
\hline IDENTITAS MEREK & 0,711 \\
\hline KUALITAS PRODUK & 0,697 \\
\hline MINAT BELI ULANG & 0,550 \\
\hline \multicolumn{2}{|l|}{ Sumber: Data primer, diolah 2018 }
\end{tabular}

Untuk uji Discriminant Validity indikator dengan program SmartPLS 3.0 dapat dilihat dari nilai Cross Loading dan Fornell - Larcker. Metode ini adalah metode lain untuk menilai Discriminant Validity. Ini dilakukan dengan membandingkan akar kuadrat dari Average Variance Extracted (AVE) untuk setiap konstruk dengan korelasi antara konstruk dengan konstruk lainnya dalam model. Untuk mendapatkan nilai tersebut pada PLS algoritma pilih Discriminant Validity lalu pilih Fornell-Larcker Criterium. Hasil dari FornellLarcker Criterium dapat dilihat pada tabel 4

Tabel 3. Fornell-Larcker Criterium

\begin{tabular}{|c|c|c|c|c|c|c|}
\hline & $\begin{array}{c}\text { CI } \\
\text { TR } \\
\text { ME } \\
\text { RE } \\
\text { K }\end{array}$ & $\begin{array}{c}\text { CITR } \\
\text { ARO } \\
\text { DUK }\end{array}$ & $\begin{array}{c}\text { HAR } \\
\text { GA }\end{array}$ & $\begin{array}{c}\text { TITA } \\
\text { S ME } \\
\text { REK }\end{array}$ & $\begin{array}{c}\text { KUAL } \\
\text { I TAS } \\
\text { PRO } \\
\text { DUK }\end{array}$ & $\begin{array}{c}\text { MI } \\
\text { NAT } \\
\text { BELI } \\
\text { ULA } \\
\text { NG }\end{array}$ \\
\hline $\begin{array}{c}\text { CI TRA } \\
\text { MEREK }\end{array}$ & 0,902 & & & & & \\
\hline $\begin{array}{c}\text { CI TRA } \\
\text { PRO } \\
\text { DUK }\end{array}$ & 0,892 & 0,694 & & & & \\
\hline HARGA & 0,610 & 0,628 & 0,717 & & & \\
\hline $\begin{array}{c}\text { IDENTI } \\
\text { TAS } \\
\text { ME } \\
\text { REK }\end{array}$ & 0,602 & 0,611 & 0,687 & 0,871 & & \\
\hline $\begin{array}{c}\text { KUALI } \\
\text { TAS } \\
\text { PRO } \\
\text { DUK }\end{array}$ & 0,588 & 0,608 & 0,654 & 0,640 & 0,757 & \\
\hline $\begin{array}{c}\text { MI NAT } \\
\text { BELI U } \\
\text { LANG }\end{array}$ & 0,539 & 0,598 & 0,601 & 0,621 & 0,643 & 0,701 \\
\hline \begin{tabular}{c} 
Sumb \\
\hline
\end{tabular} & & & & & \\
\hline
\end{tabular}

Sumber: Data primer, diolah 2018

Model mempunyai Discriminant Validity yang cukup jika akar AVE untuk setiap konstruk lebih besar daripada 
korelasi antara konstruk lainnya dari data tabel 4 dapat disimpulkan bahwa akar AVE konstruk Citra Merek (X1) sebesar 0,902 lebih tinggi dari pada korelasi antara konstruk Citra Merek (X1) dengan konstruk lainnya. Hal ini juga berlaku untuk yang lainnya, yaitu akar AVE konstruk Kualitas Produk (X2) sebesar 0,757 lebih tinggi dari pada korelasi antara konstruk Kualitas Produk (X2) dengan konstruk lainnya. Begitu pun dengan akar AVE konstruk Harga (X3) sebesar 0,717 lebih tinggi daripada korelasi antara konstruk Harga (X3) dengan konstruk lainnya.Dan akar AVE konstruk Minat Beli Ulang (Y) sebesar 0,701.Jadi semua konstruk dalam model yang diestimasi memenuhi kriteria Discriminant Validity.

\section{Cronbach's alpha}

Pada Smart 3.0 untuk mengukur reliabilitas suatu konstruk dengan indikator, yang kedua dapat dilakukan dengan melihat Cronbach's alpha pada PLS algoritma. Hasil perhitungannya diperoleh : Citra Merek 0,810, Citra Produk 0,730; Harga 0,765; Identitas Merek 0,768; Kualitas Produk 0,820; dan Minat Beli Ulang 0,733. Konstruk dinyatakan reliable jika nilai cronbach's alpa di atas 0,70. Berdasarkan angka angka diatas, baik untuk konstruk Citra Merek (X1), Kualitas Produk (X2), Harga (X3) dan Minat Beli Ulang (Y) semuanya di atas 0,70. Jadi dapat disimpulkan bahwa konstruk memiliki reliabilitas yang baik

Berikutnya dilakukan Evaluasi Model Struktural atau Inner Model Untuk melihat Pengaruh. Hasilnya RSquare sebesar 0,751 yang dapat diinterprestasikan bahwa variabilitas yang dapat dijelaskan 59,4\% sedangkan sisanya 41,6\% dijelaskan oleh variabel lain di luar yang diteliti.

Uji yang kedua melihat signifikansi pengaruh Citra Merek (X1), Kualitas Produk (X2), Harga (X3) terhadap Minat Beli Ulang (Y) secara parsial dengan melihat nilai signifikansi T-Statistik. Hasilnya variabel Identitas Merek berpengaruh positif terhadap Citra Merek. Variabel Dimensi Citra Produk dengan nilai T statistik sebesar 15,124 signifikan artinya variabel Citra Produk berpengaruh positif terhadap Citra Merek. Variabel Citra Merek (X1) dengan nilai $\mathrm{T}$ statistik sebesar 2,649 signifikan artinya variabel Citra Merek berpengaruh positif terhadap Minat Beli Ulang. Variabel Kualitas Produk (X2) dengan nilai $\mathrm{T}$ statistik sebesar 3,102 signifikan artinya variabel Kualitas Produk berpengaruh positif terhadap Minat Beli Ulang. Variabel Harga (X3) dengan nilai $\mathrm{T}$ statistik sebesar 5,341 signifikanartinya variabel Harga berpengaruh positif terhadap Minat Beli Ulang. Variabel yang paling berpengaruh terhadap Minat Beli Ulang (Y) adalah Kualitas Produk (X2), hal tersebut dapat dilihat berdasarkan nilai T Statistik tertinggi 3,102

\section{KESIMPULAN}

Setelah dilakukan penelitian, dan sesuai dengan tujuan penelitian, maka dapat diambil kesimpulan sebagai berikut : Variabel Citra Merek yang terdiri dari dimensi Identitas Merek dan Citra poduk berpengaruh positif terhadap Minat Beli Ulang Produk. Variabel Kualitas Produk yang terdiri dari indikator tampilan produk yang menarik, variasi pilihan produk, dan ketahanan produk berpengaruh positif terhadap Minat Beli Ulang Produk. Variabel Harga yang terdiri dari indikator kesesuaian harga dan kualitas, daya saing harga, dan harga terjangkau berpengaruh positif terhadap Minat Beli Ulang Produk. Variabel yg paling berpengaruh terhadap minat pembelian ulang produk kecantikan Wardah adalah kualitas produk

\section{SARAN}

Karena Variabel Citra Merek dan Harga Berpengaruh terhadap Minat beli ulang Produk kecantikan ini, maka disarankan agar PT PTI tetap mempertahankan strategi untuk kedua variabel ini. PT.PTI sebaiknya meningkatkan kualitas produknya, karena hal ini merupakan variabel yang paling berpengaruh terhadap minat beli ulang konsumen. Kedepannya diharapkan dilakukan penelitian lebih lanjut dengan variabel Promosi, Selebritas yang diendorsed dan responden dari kota kota lain seperti Medan, Makassar dan Yogyakarta dan Surabaya, agar penelitian lebih luas cakupannya dan lebih bermakna bagi strategi perusahaan kosmetik ini.

\section{DAFTAR PUSTAKA}

Arinita Febrianti Wahyudi, Bambang Irawan, N. Ari Subagio, 2014. Pengaruh, Citra Merek, Kualitas Produk, Dan Harga Terhadap Perpindahan Merek, Artikel Ilmiah Mahasiswa.

Aristia Rosiani Nugroho, Angela Irena, The Impact of Marketing Mix, Consumer's Characteristics, and Psychological Factors to Consumer's Purchase Intention on Brand "W" in Surabaya, iBuss Management Vol. 5, No. 1, (2017) 55-69

Destalianiko. A. 2017. Pengaruh Kualitas Produk, Citra Merek, dan Harga Pada Keputusan Membeli Lipstic Wardah.

https://repository.usd.ac.id/12796/2/132214100_full .pdf. (diakses 12 Agustus 2018).

Frontier Consulting Group. 2018.Top Brand Award Fase 1 2018. http://www.topbrand-award.com/top-brandsurvey/survey-result/top_brand_index_2018_fase_1 (diakses 12 Agustus 2018).

Gary Armstrong, Philip Kotler, Valerie Thrifts, Lily Anne Buchwitz, 2017, Marketing an Introduciton, 6th ed, Toronto: Pierson Canada Inc.

Hasan Ali, 2013, Marketing, Cetakan Pertama, Yogyakarta: Media Pressdindo.

Ikanita, Analisis pengaruh citra merek, kualitas produk dan harga terhadap minat beli konsumen Oriflame, Diponegoro Journal of Management, Volume 1, Nomor 1, Tahun 2012, Halaman 1

J. Paul Peter dan Jerry Olson, , 2014 Consumer Behavior and Marketing Strategy, 10th ed, New York, McGraw-Hill Education. 
Jean Noel Kapferer,2008,The new Strategic brand management,4th ed, Philadelphia: Kogan.

Kevin Lane Keller, Strategic Brand Management.4th ed New Jersey. Pearson Education Limited

Leon G. Schiffman - Joseph L. Wisenblit, 2015, Consumer Behavior, 11th ed, New Jersey: Pearson Education Limited.

Michael R Solomon, Gregg W Marshall, ElNora W Stuart, 2018, Marketing, Real People Real Choices, 9th ed, New Jersey: Pearson Education Inc.

Putri Ayuniah, 2017, Analisis Pengaruh Citra Merek, Kulaitas produk, iklan dan harga Terhadap Keputusan Pembelian Produk Kosmetik Wardah (Studi Kasus Pada Mahasiswa Jurusan Manajemen
Fakultas Ekonomi Universitas Gunadarma Depok) Jurnal Ekonomi Bisnis Volume 22 No.3, Desember. Sugiyono. 2012. Memahami Penelitian Kualitatif. Bandung: CV. Alfabeta

Tjiptono Fandy dan Diana A. 2016, Pemasaran Esensi dan Aplikasi. Edisi satu. Yogyakarta : Andi Offset.

William D. Perreault Jr, Joseph P. Cannon dan E. Jerome McCarthy,2017,Essentials of Marketing A Marketing Strategy Planning Approach, 15th ed, New York, McGraw-Hill Education.

\section{UCAPAN TERIMA KASIH}

Terimakasih pada Universitas Trilogi yang telah mendanai penelitian ini. 